\title{
KOMPLEKS PENINGGALAN SEJARAH PABRIK GULA TASIKMADU SEBAGAI WAHANA EDUKASI DAN REKREASI SISWA SEKOLAH DASAR
}

\author{
Fauzi Rachman ${ }^{1}$, Toni Harsan ${ }^{2}$ \\ Program Studi Pendidikan Sejarah ${ }^{1}$, Program Studi PPKn ${ }^{2}$, Universitas Veteran Bangun Nusantara ${ }^{1,2}$ \\ Email: fauzirachman.univetbantara.ac.id ${ }^{1}$, toniharsan@univetbantara.ac.id $^{2}$
}

\begin{abstract}
Abstrak
Tujuan dari penelitian ini adalah mengetahui: untuk mengetahui jenis Peninggalan Sejarah Pabrik Gula Tasikmadu yang dapat dimanfaatkan sebagai edukasi dan rekreasi di SD, untuk mengetahui kriteriakriteria yang digunakan dalam menentukan kelayakan pemanfaatan Peninggalan Sejarah Pabrik Gula Tasikmadu sebagai edukasi dan rekreasi di SD, untuk mendapatkan data-data pemanfaatan Peninggalan Sejarah Pabrik Gula Tasikmadu sebagai edukasi dan rekreasi di SD, untuk mengetahui kesulitankesulitan yang dihadapi guru dalam memanfaatkan Peninggalan Sejarah Pabrik Gula Tasikmadu sebagai wahana edukasi dan rekreasi di SD. Model penelitian yang digunakan adalah penelitian kualitatif yaitu dengan observasi, wawancara, dokumentasi dan studi pustaka untuk mendapatkan data-data yang digunakan sebagai pendukung. Data dianalisis dengan menggunakan beberapa tahap, yakni reduksi data, penyajian data, dan kesimpulan. Data dianalisis dengan menggunakan beberapa tahap, yakni reduksi data, penyajian data, dan kesimpulan. Berdasarkan Eksistensi Peninggalan Sejarah Pabrik Gula Tasikmadu yang dapat dimanfaatkan sebagai edukasi dan rekreasi di SD dapat disimpulkan penggunaan dapat menjadi alternatif wahana edukasi dan rekreasi yang efektif dan efisien untuk menarik remaja belajar tentang peninggalan sejarah khususnya sejarah lokal Kabupaten Sukoharjo.
\end{abstract}

Kata kunci: Peninggalan Sejarah, Edukasi dan Rekreasi

\section{COMPLEX HISTORICAL HERITAGE OF SUGAR FACTORY TASIKMADU AS A WORK OF EDUCATION AND RECREATION FOR STUDENTS IN BASIC SCHOOL}

\author{
History of Educational Program, Civic of Educational Program ${ }^{2}$, Universitas Veteran Bangun \\ Nusantara ${ }^{1,2}$

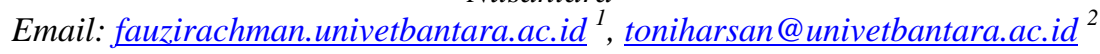

\begin{abstract}
The purpose of this research is to know the type of Tasikmadu Sugar Tree History that can be used as education and recreation in elementary school, to know the criteria used in determining the feasibility of the benefit of Tasikmadu Sugar Factory Heritage as education and recreation in SD, utilization data Historical Relics of Tasikmadu Sugar Factory as education and recreation in elementary school, to know the difficulties that are developing in utilizing Tasikmadu Sugar Tree History as a vehicle for education and recreation in elementary school. The research model used is qualitative research that is by observation, interview, documentation and study data library data used as support. Data were analyzed by using several steps, namely data reduction, presentation data, and decision. Data were analyzed by using several steps, namely data reduction, presentation data, and decision. Based on the existence of historical relics of Tasikmadu Sugar Factory which can be utilized as education and recreation in elementary school can be understood the usage can be an alternative of educational and recreational vehicle which is effective and efficient to attract youth learn about historical relics especially local history of Karanganyar Regency.
\end{abstract}

Keywords: Historical Heritage, education and recreation 


\section{PENDAHULUAN}

Pergerakan reformasi di Indonesia secara garis besar menuntut diterapkannya prinsip demokrasi, desentralisasi, keadilan, dan menjunjung tinggi hak asasi manusia dalam kehidupan berbangsa dan bernegara. Dalam hubungannya dengan pendidikan prinsip-prinsip tersebut akan memberikan dampak yang mendasar pada perbaikan mutu dan manajemen sistem pendidikan. Seiring dengan perkembangan ilmu pengetahuan, teknologi, dan arus globalisasi telah membawa perubahan di setiap aspek kehidupan. Hal ini memerlukan respon dari kinerja pendidikan yang profesional dan bermutu tinggi. Dalam menghadapi berbagai perubahan dengan permasalahan yang ditimbulkan menuntut upaya peningkatan mutu pendidikan yang diperlukan untuk mendukung terciptanya manusia yang cerdas, berkehidupan yang damai, demokrasi, dan mampu bersaing secara terbuka di era global. Maka sangatlah perlu melakukan upaya pembaharuan di bidang pendidikan (Depdikbud, 1999: 3).

Pendidikan nasional berfungsi mengembangkan kemampuan dan membentuk watak serta peradaban bangsa yang bermartabat dalam rangka mencerdaskan kehidupan bangsa, bertujuan untuk berkembangnya potensi peserta didik agar menjadi manusia yang beriman dan bertakwa terhadap Tuhan Yang Maha Esa, berakhlak mulia, sehat, berilmu, cakap, kreatif, mandiri dan menjadi warga negara yang demokratis (UU Sisdiknas, 2003: 7). Pendidikan di Indonesia cenderung bersifat akademis atau intelektualistis, dinilai sarat dengan teori dan lebih mementingkan penguasaan materi tanpa mementingkan adanya pembentukan moral. Dalam konteks ini prestasi akademis para siswa masih rendah bila dibandingkan dengan negaranegara lain. Berdasarkan hasil penelitian di Asia tentang penyelenggaraan pendidikan di setiap negara, ternyata Indonesia berada pada peringkat ke-13 setelah Vietnam (Depdikbud, 2003: 5). Hal ini tidak terkecuali untuk pembelajaran bidang studi sejarah.

Pelajaran sejarah di samping bersifat akademis, juga melatih ketrampilan memecahkan masalah dan merekonstruksi peristiwa, serta terkait dengan kearifan dan pelajaran moral (Sardiman, 2002: 1). Soejatmiko dalam Nusa Putra (1993: 64) menjelaskan bahwa perintisan hari depan pada hakekatnya bersumber dari perenungan sejarah dan kehidupan masa lampau. Pendidikan sejarah diarahkan sebagai usaha untuk meningkatkan kepekaan anak untuk ikut menunjang kehidupan bersama yang lebih baik, melalui refleksi nilai masa lampau. I Gde Widja (2002: 33) mengemukakan bahwa mata pelajaran sejarah diajarkan sebagai sarana pewarisan budaya (cultural tranmission) dalam rangka proses sosialisasi dan enkulturasi untuk mewujudkan penumbuhan jati diri generasi baru. I Gde Widya (2002: 33) juga 
menambahkan bahwa sejarah merupakan pelajaran yang paling berharga, bukan saja tentang kehidupan dan perjuangan bangsa Indonesia, namun juga sejarah tentang bangsa-bangsa lain di dunia. Dalam penjelasan Depdiknas (1999: 2), dipaparkan bahwa dari bidang studi sejarah suatu bangsa bisa menimba berbagai pengalaman penting baik kehidupan di masa kini maupun untuk masa mendatang.

Pernyataan Menteri Pendidikan dan Kebudayaan waktu itu Bapak Juwono Sudarsono, yang cukup menggelitik akan pentingnya perombakan kembali kurikulum sejarah Nasional (Kompas, 8 Oktober 1987). Pernyataan tersebut cukup beralasan, disebabkan metode ceramah yang bersifat monoton dan kurang bervariasi menyebabkan guru mendominasi kegiatan dalam proses belajar-mengajar, guru tidak punya waktu untuk memberikan kesempatan pada siswa untuk berpikir kreatif. Siswa diperlakukan secara pasif, duduk terpaku diam berperan sebagai pendengar setia dari waktu ke waktu. Dalam hal ini sebagian besar siswa hanya bersifat pasif saat mengikuti proses belajar-mengajar mata pelajaran sejarah. Syaiful Bahri Djamarah (2002: 206) mengungkapkan bahwa metode ceramah yang monoton sangat menjenuhkan dan membosankan, berakibat minat belajar siswa terhadap mata pelajaran sejarah sangat rendah.

Dalam menyampaikan materi pelajaran sejarah, guru hanya berpegangan pada buku sejarah yang berlaku di sekolah-sekolah. Guru sejarah kebanyakan ada yang hanya mempelajari materi yang ada dalam bukubuku tersebut. Guru dalam menyampaikan materi hanya berpedoman pada satu buku bacaan. Teknik demikian semakin menjadikan mata pelajaran sejarah tidak diminati oleh siswa, dan siswa menjadi malas mempelajari materi pelajaran sejarah karena sudah lelah mencatat terus menerus. Masalah-masalah tersebut, perlu dilakukan upaya pembaharuan dan pengembangan media pembelajaran. Media atau sumber belajar yang dapat digunakan dalam mata pelajaran sejarah yang tergabung dalam IPS terpadu di SD adalah peta, gambar, globe (bola dunia), benda-benda material seperti OHP, film strip, audio tape, video tape dan sebagainya.

Keberadaan Obyek Wisata Sondokoro atau Perusahaan Gula Tasikmadu beserta peninggalan-peninggalannya merupakan warisan sejarah kolonial Belanda tentang perkembangan industri perkebunan tebu di wilayah Mangkunegaran dan bangunanbangunan yang mempunyai nilai historis tinggi. Pemanfaatan Obyek Wisata Sondokoro atau Perusahaan Gula Tasikmadu sebagai obyek wisata sejarah dan sumber belajar sejarah diharapkan dapat dijadikan wahana edukasi dan rekreasi nostalgia sejarah masa lampau industri tebu di wilayah Mangkunegaran dan dapat memperkaya pengetahuan sejarah, serta dapat menumbuhkan minat yang besar pada 
siswa untuk mempelajari sejarah secara lebih serius, menarik dan kreatif. Melalui kunjungan ke obyek sejarah secara langsung dapat mengubah anggapan bahwa siswa yang mempelajari sejarah bukan sesuatu yang membosankan dan menjenuhkan tetapi merupakan sesuatu yang menarik dan menyenangkan.

\section{METODE PENELITIAN}

Ditinjau dari masalah yang diselidiki, teknik dan alat yang digunakan serta tempat dan waktu penelitian yang dilakukan penelitian ini adalah penelitian deskriptif kualitatif. Penelitian deskriptif kualitatif terdiri dari beberapa jenis, salah satunya adalah penelitian kasus atau studi kasus. Studi kasus merupakan penelitian yang fokus permasalahannya terletak pada fenomena kontemporer (masa kini) di dalam konteks kehidupan nyata, di mana batasan antara fenomena dengan konteks tersebut tidak jelas, sehingga diperlukan banyak sumber-sumber fakta (Miles dan Huberman., 1992: 10). Penelitian ini, menggunakan studi kasus karena penelitian mengkaji mengenai bagaimana Pabrik Tebu Tasikmadu sebagai Obyek Wisata Sejarah dan Sumber Pembelajaran Sejarah Siswa SD Negeri Kabupaten Karanganyar. Strategi penelitian yang disebut studi kasus terpancang tunggal. Metode studi kasus penelitian ini berupa satu obyek wisata sejarah yaitu Pabrik Tebu Tasikmadu yang terletak di Kabupaten
Karanganyar yang mempunyai karakteristik masyarakat agraris.

Sumber data adalah suatu tempat data diperoleh. Dalam penelitian kualitatif ini sumber data yang diperlukan adalah data dan tindakan, selebihnya adalah data tambahan seperti dokumen, foto, sumber data tertulis, tempat kegiatan. Guna memperoleh data informasi yang berkaitan dengan masalah dan tujuan penelitian ini, maka sumber data diambil dari: a) sumber benda, tempat dan peristiwa, b) informan, c) sumber tertulis atau dokumen. Berikut ini merupakan penjelasan tentang sumbersumber data tersebut di atas:

Adapun yang termasuk sumber benda dalam penelitian ini adalah bangunan fisik Pabrik Gula Tasikmadu dan benda-benda peninggalan Pabrik Gula Tasikmadu. Sedangkan peristiwa yang dimaksud adalah sejarah perkembangan industri perkebunan tebu di Mangkunegaran khususnya wilayah Kabupaten Karanganyar dan sekitarnya yang ada kaitannya dengan permasalahan penelitian.

Untuk mencari data melalui informan dalam penelitian ini informan-informan yang menjadi sumber data yaitu Pengelola Obyek Wisata Sondokoro / Pabrik Gula Tasikmadu, Guru sejarah SD Negeri Kabupaten Karanganyar yang pernah mengadakan kegiatan study tour ke Pabrik Gula Tasikmadu, serta siswa SD Negeri Kabupaten Karanganyar yang pernah 
mengikuti kegiatan sekolah study tour ke Pabrik Gula Tasikmadu

Teknik Pengumpulan Data dalam penelitian ini peneliti menggunakan teknik observasi langsung, yaitu peneliti langsung mengadakan pengamatan di tempat penelitian. Wawancara Penelitian ini menggunakan teknik wawancara mendalam dan teknik wawancara terbuka. Analisis dokumen yang diperoleh dari SD Negeri Kabupaten Karanganyar yaitu berupa kurikulum mata pelajaran sejarah dan dokumen tentang Pabrik Gula Tasikmadu.

Teknik Sampling suatu teknik yang digunakan untuk memilih orang yang akan dijadikan informan, informan kunci (keys informan) yang menjadi kunci awal penelitian yang mengarahkan pada sumber informan yang lainnya, informan-informan kunci tersebut yaitu Pengelola Sub Bidang Publikasi dan Promosi Nilai-nilai peninggalan sejarah pabrik gula Tasikmadu. Guru kelas dan Siswa SD Negeri Kabupaten Karanganyar yang pernah mengadakan kegiatan study tour ke Pabrik Gula Tasikmadu.

Proses validitas data, penelitian ini mempergunakan dua teknik trianggulasi, yaitu trianggulasi data dan trianggulasi metode.

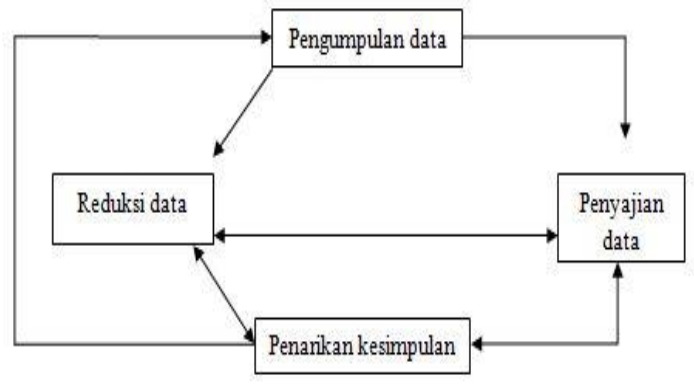

Gambar 1. Proses Analisis Data Kualitatif Miles dan Huberman (1992: 16)

Teknis Analisis Data yang dipergunakan empat komponen yaitu pengumpulan data, reduksi data, sajian data, dan penarikan kesimpulan/verifikasi, yang dilakukan selama penelitian.

\section{HASIL DAN PEMBAHASAN}

Kegiatan belajar mengajar bukan berproses dari ketiadaan tetapi berproses dari kebermaknaan. Kegiatan pembelajaran mengandung sejumlah nilai yang disampaikan kepada anak didik. Nilai-nilai itu tidak datang dengan sendirinya tetapi diambil dari berbagai sumber guna dipakai dalam proses belajar mengajar, salah satunya adalah lingkungan.

Lingkungan terdiri atas lingkungan fisik dan non fisik. Lingkungan fisik seperti gedung sekolah, perpustakaan, laboratorium, studio, auditorium, taman dan lain-lain. Lingkungan non fisik seperti penerangan sirkulasi udara dan lain-lain. 
Selanjutnya lingkungan yang disebut sebagai sumber belajar dan media pembelajaran adalah tempat atau ruangan yang dapat mempengaruhi siswa. Tempat dan ruangan tersebut ada yang dirancang (by design) khusus untuk tujuan pembelajaran, misalnya gedung sekolah; ruang perpustakaan; laboratorium, studio. Selain itu ada juga tempat atau ruangan yang bukan dirancang secara khusus atau hanya dimanfaatkan sebagai sumber belajar dan media pembelajaran untuk pengajaran, seperti gedung dan peninggalan sejarah, bangunan industry, lingkungan pertanian, museum, pasar, tempat rekreasi.

Peninggalan sejarah merupakan media pembelajaran yang berasal dari lingkungan, sehingga metode pembelajaran yang dapat digunakan untuk memanfaatkannya haruslah tepat, efektif dan efisien. Penggunaan media harus dapat menyalurkan pesan, dapat merangsang pikiran, perasaan, dan kemauan peserta didik sehingga dapat mendorong terciptanya proses belajar pada diri peserta didik.

Peninggalan sejarah di Kecamatan Tasikmadu jumlahnya ada beberapa, contohnya adalah Peninggalan Sejarah Pabrik Gula Tasikmadu. Dalam memanfaatkan peninggalan sejarah tersebut diperlukan batasan-batasan tertentu sehingga tujuan-tujuan dalam pembelajaran dapat tercapai, baik tujuan pendidikan nasional, tujuan sekolah maupun tujuan pembelajaran. Batasan-batasan dan kriteria peninggalan sejarah dapat dimanfaatkan kegiatan pembelajaran harus disesuaikan dengan Standar Kompetensi dan Kompetensi Dasar (SK/KD) IPS SD. SKKD IPS SD yang memuat tentang peninggalan sejarah di Kecamatan tasikmadu adalah SKKD Kelas IV. Pemilihan peninggalan sejarah di Kecamatan Tasikmadu sebagai media pembelajaran harus memperhatikan beberapa hal sehingga tujuan yang ingin dicapai dalam kegiatan pembelajaran dapat terwujud karena pemilihan pembelajaran yang tepat, efektif dan efisien untuk mendukung kegiatan pembelajaran.

Pemilihan peninggalan sejarah yang akan dijadikan media pembelajaran juga harus memperhatikan keadaan fisik bangunan sejarah itu sendiri. Peninggalan sejarah yang dipilih sebagai media pembelajaran IPS, keadaan fisiknya harus baik, utuh dan mampu mempresentasikan kondisi pada zamannya sehingga mampu memahami keadaan saat peninggalan sejarah itu didirikan.

Peninggalan sejarah di Kecamatan Tasikmadu yang dapat dimanfaatkan sebagai media pembelajaran adalah asal usul Kecamatan Tasikmadu, mendata peninggalan-peninggalan sejarah di kompleks pabrik gula Tasikmadu Kecamatan Tasikmadu yang bersifat peninggalan sejarah bersifat lokal seperti: Spoor Teboe, Kremon (Gerbong), Lori Bader, Bendi, Spoor Gula, Monumen Giling. 
Peninggalan sejarah merupakan media pembelajaran yang berasal dari lingkungan. Media ini tidak sengaja dibuat untuk tujuan pembelajaran sehingga guru harus teliti dan jeli dalam memilih kriteria-kriteria untuk menentukan kelayakan peninggalan sejarah ini agar dapat dimanfaatkan sebagai media pembelajaran.

Kriteria yang paling penting untuk menentukan kelayakan media peninggalan sejarah adalah peninggalan sejarah tersebut harus sesuai dengan materi yang diajarkan, dengan kata lain harus sesuai dengan kurikulum IPS yang diajarkan di SD dijabarkan dalam SKKD IPS SD Kelas IV. Peninggalan sejarah harus dalam keadaan utuh dan terawat dengan baik sehingga dapat membantu pemahaman siswa tentang materi yang sedang diajarkan.

Kriteria-kriteria penentuan kelayakan peninggalan sejarah untuk dimanfaatkan sebagai media pembelajaran ini sesuai dengan prinsip pemilihan dan penggunaan media yang disampaikan oleh Heinich dkk (dalam Azhar Arsyad, 2007: 67). Prinsip pemilihan dan penggunaan media menurut Heinich dkk adalah: 1) menganalisis karakteristik umum kelompok sasaran, artinya seorang guru dalam memilih media pembelajaran harus sesuai dengan siswa yang akan menggunakan media tersebut, karena siswa SD harus mendapat gambaran tiga dimensi terhadap segala sesuatu yang disampaikan oleh guru, maka peninggalan sejarah yang sudah mereka kenal tentu lebih baik pemahamannya bila disampaikan kepada siswa dengan menunjukkan benda yang dibicarakan; 2) menyatakan atau merumuskan tujuan pembelajaran, artinya media pembelajaran yang dipilih oleh guru harus sesuai dengan tujuan yang ingi dicapai dalam pembelajaran. Tujuan pembelajaran IPS dengan memanfaatkan media peninggalan sejarah adalah: a) menjelaskan asal usul nama suatu tempat yaitu asal usul Kecamatan Tasikmadu/Sondokoro; b) mencatat peninggalan sejarah di Kecamatan Tasikmadu yaitu: Spoor Teboe, Kremon (Gerbong), Lori Bader, Bendi, Spoor Gula, Monumen Giling; c) mengklasifikasikan jenis-jenis peninggalan sejarah, yaitu dengan mengklasifikasikan Peninggalan Sejarah Pabrik Gula sebagai peninggalan sejarah pada jaman kolonial; d) menjelaskan ciri-ciri peninggalan sejarah; e) menjelaskan cara menjaga kelestarian peninggalan sejarah; $f$ ) menjelaskan manfaat menjaga kelestarian peninggalan sejarah.

Kunjungan ke lokasi peninggalan sejarah membuat peserta didik mengetahui gambaran tentang ciri-ciri peninggalan sejarah. Mereka dapat melihat secara langsung peninggalan sejarah tersebut sehingga dapat menjelaskan ciri-ciri peninggalan sejarah tersebut. Cara pelaksanaan pembelajaran ini menjadikan peserta didik sebagai subjek pembelajaran, sehingga peserta didik dapat mengembangkan potensi diri secara optimal. Metode pembelajaran ini menuntut peserta 
didik mampu belajar mandiri, selain itu mereka menjadi bergairah dalam mempelajari IPS dan optimalisasi potensi diri peserta didik pada akhirnya akan menjadikan prestasi peserta didik menjadi optimal.

Kegiatan demonstrasi dengan menunjukkan gambar atau foto peninggalan sejarah dapat digunakan sebagai alternatif dalam pelaksanaan pembelajaran IPS dengan memanfaatkan peninggalan sejarah sebagai media pembelajaran.

Kesulitan yang dihadapi guru dalam memanfaatkan peninggalan sejarah sebagai media pembelajaran IPS SD terkait dengan pelaksanaan pembelajaran yang dipakai dalam memanfaatkan peninggalan sejarah sebagai media pembelajaran. Dalam metode karya wisata guru menghadapi kendala yaitu sulitnya mengorganisasi siswa dan masalah biaya untuk mengunjungi tempat peninggalan sejarah tersebut terutama masalah biaya akomodasi siswa dan guru. Dalam metode karya wisata siswa melaksanakan kegiatan pembelajaran di luar kelas, artinya siswa bebas bergerak tanpa dibatasi oleh dinding ruang kelas. Kondisi ini menjadikan siswa lebih suka bermainmain dari pada melaksanakan kegiatan pembelajaran. Siswa beranggapan bahwa kegiatan pembelajaran di luar kelas ini adalah bentuk lain dari bermain dan berekreasi sehingga mereka lebih mementingkan kegiatan tersebut dibandingkan kegiatan pembelajaran itu sendiri.

Kegiatan karya wisata ini adalah membawa siswa ke tempat peninggalan sejarah, dengan kata lain kegiatan ini memerlukan akomodasi agar dapat terlaksana dengan baik. Biaya akomodasi untuk membawa satu kelas siswa dengan guru tentu membutuhkan biaya yang cukup besar. Dengan latar belakang orang tua murid yang berpenghasilan kecil, maka tidak mungkin membebankan biaya karya wisata kepada siswa.

Apabila perencanaan guru sebagai fasilitator dan penyelenggara pendidikan kurang persiapan maka kegiatan belajar mengajar di lokasi peninggalan sejarah tidak dapat berlangsung secara optimal terutama jika yang menjadi peserta adalah siswa SD. Guru dapat memberikan pengarahan dan bimbingan baik sebelum kegiatan di luar sekolah maupun saat kegiatan belajar mengajar dengan memafaatkan peninggalan sejarah berlangsung. Arahan dan bimbingan tersebut dapat membantu peserta didik lebih fokus dan berkonsentrasi dalam kegiatan belajar mengajar tanpa menghilangkan unsur eksplorasi dan rasa keingintahuan siswa, sehingga siswa dapat mencari tahu tentang peninggalan sejarah yang dikunjungi, ciriciri, cara memanfaatkan serta melestarikan peninggalan sejarah tersebut. Siswa didorong untuk mengajukan pertanyaanpertanyaaan seputar peninggalan sejarah yang dikunjungi sehingga mereka dapat 
lebih memahami makna dari peninggalan sejarah tersebut.

Selain itu guru dapat membentuk kelompok-kelompok kecil di mana dalam kelompok tersebut dipilih anak yang mampu memimpin sebagai ketua. Melalui ketuaketua kelompok ini guru dapat memantau pelaksanaan pembelajaran sehingga pelaksanaan pembelajaran dapat berlangsung dengan baik.

Kesulitan yang dialami guru juga menyangkut waktu pelaksanaan kegiatan belajar mengajar dengan memanfaatkan media pembelajaran peninggalan sejarah. Kegiatan belajar mengajar tidak dapat dilakukan dengan alokasi waktu yang telah ditentukan oleh sekolah. Untuk itu perlu mencari waktu selain waktu pembelajaran di kelas yang telah ditentukan oleh sekolah, misalnya waktu libur. Pemanfaatan waktu liburan ini untuk kegiatan pembelajaran selain sebagai sarana rekreasi juga menjadi edukasi yang terarah.

Biaya juga menjadi kendala yang cukup memberatkan guru untuk menyelenggarakan kegiatan belajar mengajar dengan memanfaatkan peninggalan sejarah sebagai media pembelajaran. Salah satu cara yang dapat dilakukan adalah dengan mengalokasikan sebagian dana BOS yang diterima sekolah untuk kegiatan ini.

\section{KESIMPULAN DAN SARAN}

Berdasarkan pada sajian data, pokok temuan penelitian dan pembahasan dapat disimpulkan bahwa peninggalan sejarah di Kecamatan Tasikmadu yang dapat dimanfaatkan sebagai media pembelajaran IPS/Sejarah SD adalah peninggalan sejarah yang sesuai dengan Kompetensi Dasar (KD) Mata Pelajaran IPS SD, KD yang sesuai dengan deskripsi ini adalah KD Kelas IV Semester I yaitu: "Menghargai berbagai peninggalan sejarah di lingkungan setempat (Kabupaten/Kota, Provinsi) dan menjaga kelestariannya".

Sebelum melaksanakan kegiatan pembelajaran dengan memanfaatkan peninggalan sejarah Kecamatan Tasikmadu sebagai media pembelajaran perlu dibuat perencanaan pembelajaran dan perangkat pembelajaran meliputi program tahunan, program semester, silabus dan rencana pelaksanaan pembelajaraan (RPP). Pemanfaatan peninggalan sejarah sebagai media pembelajaran dapat berjalan dengan lancar, efektif dan efisien.

Saran ini ditujukan untuk pengelola Peninggalan Sejarah Pabrik Gula Tasikmadu untuk lebih memberikan akses pengunjung khususnya pelajar melihat-lihat peninggalan sejarah berupa mesin-mesin pabrik gula yang masih beroperasi di dalam kompleks Pabrik gula Tasikmadu. Penulis juga menyarankan kepada peneliti lain untuk melakukan penelitian lebih lanjut mengenai peran dan keberadaan dari peninggalanpeninggalan bersejarah lainnya di Kabupaten Karanganyar, selain Peninggalan Sejarah Pabrik Gula Tasikmadu, yang 
mempunyai pengaruh besar terhadap kejayaan industri gula pada jaman kolonial Belanda.

\section{DAFTAR PUSTAKA}

Depdiknas. 1999. Kongres Nasional Sejarah 1996 Sub Tema Pemikiran dan Analisis Teks Sejarah. Jakarta: CV. Ilham Bangun Karya.

Depdikbud. 2003. Pengelolaan Kurikulum di Tingkat Sekolah. Jakarta: Departemen Pendidikan Nasional.

I Gde Widja. 2002. Menuju Wajah Baru Pendidikan Sejarah. Yogyakarta: Lappera Pustaka Utama. Cipta
Miles dan Huberman. 1992. Analisis Data Kualitatif (Terjemahan Tjetjep Rohendi Rohidi). Jakarta : UI Press.

Restu Gunawan dkk. 1998. Simposium Pengajaran Sejarah. Jakarta: Proyek Inventarisasi Sejarah Nasional Pendidikan dan Kebudayaan.

Sardiman A. M. 2002. Pengembangan Kurikulum Sejarah Menuju Kurikulum Berbasis Kompentensi. Surakarta: UNS Press.

Syaiful B. Djamarah. 2000. Guru dan Anak Didik dalam Interaksi Edukatif. Jakarta: P.T. Rineka Cipta.

UU Sisdiknas. 2003. Undang-undang Republik Indonesia No. 20 tahun 2003. Jakarta: Sinar Grafika.

“Mau diapakan lagi Pengajaran Sejarah". 1987. Mei 25. Kompas. 4. 